\title{
Properties of Functionally Gradient Composite Consisting of Hydroxyapatite Containing Glass Coated Titanium and Characters for Bioactive Implant
}

\author{
Shigeo MARUNO, Seiji BAN*, Yun-Fu WANG ${ }^{\dagger}$, Hisashi IWATA** and Haruo ITOH*** $^{* *}$ \\ Nagoya Institute of Technology, Gokiso-cho Showa-ku, Nagoya-shi 466 \\ *Schl. of Dentistry, Aichi-Gakuin Univ., Kusumoto-cho, Chikusa-ku, Nagoya-shi 464 \\ **Dept. of Orthopedic Surg., Nagoya Univ., Tsurumai-cho, Showa-ku, Nagoya-shi 466 \\ ***Tokyo Kouseinenkin Hosp., Tsu, Shinjuku-ku, Tokyo 162

\section{ハイドロキシアパタイト含有ガラスーチタン傾斜機能複合材料の物性と 生体活性インプラントとしての特性} \\ 丸野重雄・伴 清治*・王 允夫 $\cdot$ 岩田 久**・伊藤晴夫*** \\ 名古屋工業大学電気情報工学科, 466 名古屋市昭和区御器所町 \\ *愛知学院大学歯学部歯科理工学教室, 464 名古屋市千種区楠元町 1-100 \\ **名古屋大学医学部整形外科, 466 名古屋市昭和区鶴舞町 65 \\ ***東京厚生年金病院整形外科, 162 東京都新宿区津 5-1 \\ [Received November 5, 1991; Accepted February 18, 1992]
}

\begin{abstract}
Composites comprising hydroxyapatite (HA) containing glass layer and pure titanium or $\mathrm{Ti}-6 \mathrm{Al}-4 \mathrm{~V}$ alloy, so called HA-G-Ti functionally gradient materials, have been shown to be useful for bioactive artificial joints and dental implants. In the present study, the mechanical and thermal properties of the HA containing glasses were examined. The compressive strength of $\mathrm{HA}$ containing glasses less than $70 \mathrm{wt} \% \mathrm{HA}$ content was sufficiently larger than that of bone. The hardness of about $70 \mathrm{wt} \% \mathrm{HA}$ containing glass corresponded to that of natural teeth. It has been found from DSC analysis that the glass little reacts with $\mathrm{HA}$ at firing temperature $\left(950^{\circ} \mathrm{C}\right)$. Thermal expansion coefficients of $\mathrm{HA}$ containing glasses with relatively low $\mathrm{HA}$ content were suitable values for the coating on $\mathrm{Ti}$ and $\mathrm{Ti}-6 \mathrm{Al}-$ $4 \mathrm{~V}$. The bonding strength of the glass to $\mathrm{Ti}$ substrate reached the maximum value of $28 \mathrm{MPa}$ under the condition of $2.3 \mu \mathrm{m}$ in surface roughness (center line average). The HA-G-Ti composites with bioactive surface, etched in a mixture of $\mathrm{HF}$ and $\mathrm{HNO}_{3}$, showed a good apposition to the bone in vivo.
\end{abstract}

Key-words : Hydroxyapatite, Glass, Titanium, Coating, Composite, Biomaterial, Implant, Functionally gradient material

\section{Introduction}

It is well known that hydroxyapatite $\mathrm{Ca}_{10}\left(\mathrm{PO}_{4}\right)_{6}$ $(\mathrm{OH})_{2}$, hereafter abbreviated to $\mathrm{HA}$, is a bioactive ceramic having excellent biocompatibility with the body environment, ${ }^{1-4)}$ and that pure titanium and titanium alloy such as Ti-6Al-4V with sufficient mechanical strength are suitable metals exhibiting good biological stability and affinity. In recent years, particular attention has been drawn to the use of HA-coated implants for hip prostheses and a dental

\footnotetext{
†現在 : 中国軽工業部ガラス泆瑯工業研究所

Present address : The Glass and Enamel Research Institute, Ministry of Light Industry, China
}

implants in which HA layer is coated on the surface of titanium substrate by plasma spraying(5),6) and sputtering. ${ }^{7)}$ However, there is a problem of change of chemical composition and structure due to the thermal decomposition of HA under high temperature in plasma process, ${ }^{8)}$ and the HA coating layer with more than $50 \mu \mathrm{m}$ in thickness behave like a brittle ceramic and leads to the peeling. Furthermore, the large difference in the linear thermal expansion coefficient between the HA coating layer and the titanium or Ti-6Al-4V substrate can cause fatigue failure under tensile load.

We developed a new composite material (HA-GTi) consisting of a substrate coated with a HA containing glass layer, wherein the layer comprises a continuous glass phase with dispersed HA particles and the surface is prepared in a roughened state. ${ }^{9), 10)}$ It has been found that the HA containing glass coated titanium composites provides both bioactivity potential due to the $\mathrm{HA}$ and the mechanical strength of titanium, and the composites are useful for biocompatible composite materials which are especially suitable for implant applications. ${ }^{11)-14)}$ The chemical stability of the glass in vitro was evaluated by both a dissolution test and an electro-chemical corrosion test in aqueous solution with a range of chemical activity. ${ }^{14), 15)}$ The roughened surface on the HAG-Ti composite resulting from chemical etching was also very important factor for biological activity, ${ }^{16)}$ because the surface portion of the HA containing glass layer was converted to a roughened state having voids and exposed HA fine particles by etching treatment. The porous surface is well known to make active effects on bone formation. ${ }^{17)}$

The development of glass frits to be employed for producing this HA-G-Ti composite is basically important. That is, the following properties are required for frits; (1) the glasses have excellent ad- 
hesiveness with substrate Ti or Ti alloy, (2) the glasses have biochemical stability for body fluid, (3) the glasses and HA don't react at firing temperature from $800^{\circ}-950^{\circ} \mathrm{C}$. The objective of this study is to examine the physical properties of the HA containing glass with different concentration of HA that constitute the HA-G-Ti composite for bioactive implant, as well as the adhesion between the HA containing glass and the substrate, and demonstrate some evidence of excellent biocompatibility as a functionally gradient composite for implant applications.

\section{Experimental}

2.1 Preparation of powder and characterization

HA powder was synthesized by a wet method using $\mathrm{H}_{3} \mathrm{PO}_{4}$ and $\mathrm{Ca}(\mathrm{OH})_{2}$ aqueous solutions. The precipitate was sufficiently washed with distilled water and then dried at $100^{\circ} \mathrm{C}$ for $16 \mathrm{~h}$. The dry precipitate was calcined at $800^{\circ} \mathrm{C}$ and subsequently fired at $1200^{\circ} \mathrm{C}$, for preparing crystalline HA.

The composition of glass frit for producing the $\mathrm{HA}-\mathrm{G}-\mathrm{Ti}$ composite was determined through numerous experiments with respect to not only the adhesion between glass and titanium but the reaction of the glass with HA under the firing process. The glass composition used in the present work is $67.7 \% \mathrm{SiO}_{2}, 10.4 \% \mathrm{~B}_{2} \mathrm{O}_{3}, 5.2 \% \mathrm{Al}_{2} \mathrm{O}_{3}, 8.3 \% \mathrm{Na}_{2} \mathrm{O}$, $4.2 \% \mathrm{~K}_{2} \mathrm{O}, 2.1 \% \mathrm{Li}_{2} \mathrm{O}, 1.05 \% \mathrm{ZrO}_{2}$ and $1.05 \% \mathrm{TiO}_{2}$ by weight. Glass frit was prepared by following procedures; the mixture of raw materials having the composition of the glass was heated up to $800^{\circ} \mathrm{C}$ over $1 \mathrm{~h}$, heated up to $1400^{\circ} \mathrm{C}$ over $1.5 \mathrm{~h}$ in the electric furnace, and then maintained at $1400^{\circ} \mathrm{C}$ for $1.5 \mathrm{~h}$, followed by rapid cooling in water.

The obtained HA blocks and glass frit were pulverized by means of a pot mill made of alumina for $36 \mathrm{~h}$, followed by sifting with a sieve of 350 mesh (Tyler), to prepare a powdery HA and glass having a particle size of $44 \mu \mathrm{m}$ or less, respectively. The HA and glass powders were subjected to X-ray diffractometry (Geigerflex RAD-II A, Rigaku) to identify pure HA polycrystal phase (as well as crystallinity) and glassy state, respectively. The powdery HA and glass were mixed so that the weight ratios of the HA to the glass became $10: 90,30: 70,50: 50,70: 30$, $90: 10$, respectively, to prepare five kinds of HAglass mixtures.

The HA-glass mixtures were separately pressed by means of a molding machine to prepare the tablets $5 \mathrm{~mm}$ in diameter and $5 \mathrm{~mm}$ in thickness. The obtained tablets were fired at $950^{\circ} \mathrm{C}$. The compressive strength, load at which the tablet was crushed, was measured with a testing machine (Instron Testing Machine 1125, Instron). The crosshead speed was $1 \mathrm{~mm} / \mathrm{min}$. These fired tablets were also subjected to Vickers hardness measurement under load conditioning of $500 \mathrm{~g}$ weight for $30 \mathrm{sec}$ (MVK-D, Akashi). In addition, the powder samples of these fired tablets were subjected to X-ray diffrac- tion and differential scanning calorimetry (DSC) analysis (Standard type, Rigaku) to confirm whether the HA did react with the glass at the firing temperature $950^{\circ} \mathrm{C}$ or not.

The HA-glass mixtures were pressed by means of a molding machine to prepare the rod $3 \mathrm{~mm}$ in diameter and $12 \mathrm{~mm}$ in length. The rods were fired at $950^{\circ} \mathrm{C}$ to $1050^{\circ} \mathrm{C}$. The sintered rods were subjected to thermal micro-analysis (Thermoflex TMA 8140, Rigaku) to measure thermal expansion curve from room temperature to $600^{\circ} \mathrm{C}$. The thermal expansion coefficients were determined by the slope at the temperature range from $30^{\circ} \mathrm{C}$ to $400^{\circ} \mathrm{C}$ for each sample.

\subsection{Coating and bonding test}

We used a pure Ti rod $3.1 \mathrm{~mm}$ in diameter and 50 $\mathrm{mm}$ in total length for the substrate in this study. The surface of Ti rod was sandblasted with alumina powder to produce various surface average roughness $\left(H_{\mathrm{CLA}}\right)$ in the range of from 0.2 to $6.8 \mu \mathrm{m}\left(H_{\mathrm{CLA}}\right.$ : center line average value, $0.2,2.3,3.3,5.0$ and 6.8 $\mu \mathrm{m})$. After cleaning, the slips of the glass frit or the mixture of glass and HA powder, and a sandblasted Ti rod were set in a carbon die so that a joint between the glass powder and the Ti rod became 10 $\mathrm{mm} \phi \times 10 \mathrm{~mm}$ height and fired at $950^{\circ} \mathrm{C}$ for $5 \mathrm{~min}$ or $1050^{\circ} \mathrm{C}$ for $20 \mathrm{~min}$ in an atmosphere air to form a glass-Ti composite and HA containing glass-Ti composite.

Bonding strength between coating layer and substrate was determined by means of pull-out strength test using a testing machine. Figure 1 shows the sample design and a supporting tool. The cross-head speed (pulling rate) was $1 \mathrm{~mm} / \mathrm{min}$.

Cross sections of the glass-Ti composites fired at different temperatures in air $\left(950^{\circ} \mathrm{C} / 5 \mathrm{~min}, 1030^{\circ} \mathrm{C} /\right.$ $20 \mathrm{~min}$, and $1080^{\circ} \mathrm{C} / 20 \mathrm{~min}$ ) were subjected to electron probe micro-analysis (EPMA) (JXMA-733, JOEL) for line scanning of $\mathrm{Si}, \mathrm{Ti}$, and $\mathrm{O}$ at the interface between glass and titanium.

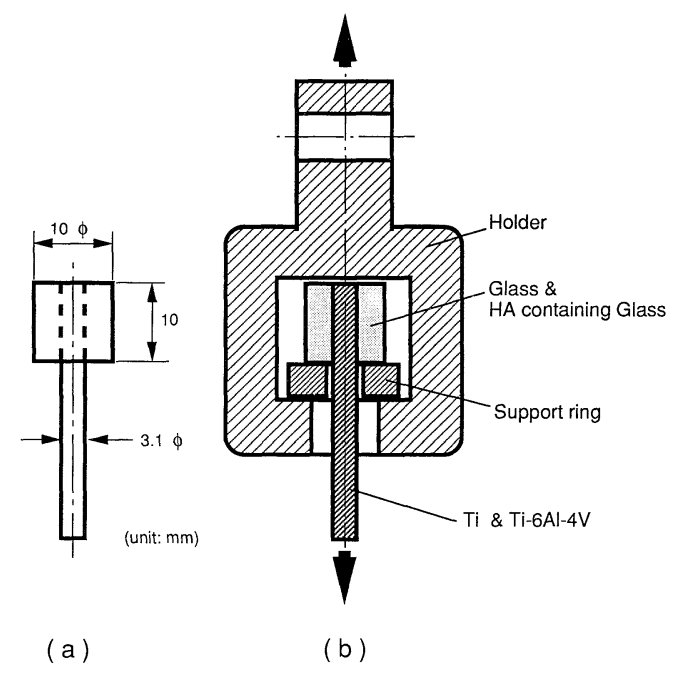

Fig. 1. Scheme of sample shape (a) and supporting tool (b) for the measurement of pull-out strength. 


\subsection{Application for implant}

The composite specimens for implant were prepared in substantially the same manner as described above except substrate size and thickness of coating layer and surface etching. Slips of mixture of the glass frit and HA powder, with different composition, were coated on the sandblasted Ti rod of 3.1 $\mathrm{mm} \phi \times 20 \mathrm{~mm}$ having an average roughness $2.3 \mu \mathrm{m}$ and fired at $800^{\circ}-900^{\circ} \mathrm{C}$ for $2-3 \mathrm{~mm}$. The HA-glass layer around $100 \mu \mathrm{m}$ in thickness was produced on Ti by repeating the coating and firing. Subsequently, the surface of the composite was etched for 2-3 min in an aqueous solution of $3 \% \mathrm{HF}$ and $5 \% \mathrm{HNO}_{3}$ to remove the surface layer covered with glass and obtain the bioactive surface layer with exposed HA particles. Figure 2 shows a schematic illustration of a cross-section of HA-G-Ti composite.

The HA-G-Ti composites were embedded in femur and tibia of Beagle dogs. The implants after elapsed of 2 month were removed together with the surrounding bone, cut using a diamond cutter. The sample blocks obtained were used for radiographic observation. The transverse sections of samples were dehydrated with serially graded alcohol and transferred to amyl acetate, followed by drying with a critical point dryer (HCP-2, Hitachi). The dried samples were subjected to SEM (S-800, Hitachi) observation.

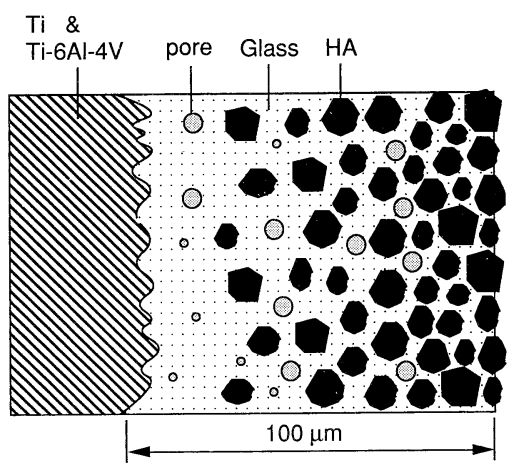

Fig. 2. Schematic illustration showing a cross-section of HAglass-titanium functionally gradient composite.

\section{Results and discussion}

\subsection{Properties of HA containing glass}

Figure 3 shows the relationship between the compressive strength and the HA content in the HA containing glass. The compressive strength of the glass decreases according to the increase of HA content in the glass, since the compressive strength of the HA particles was lower than that of the glass. The HA particles used in this study were prepared by only firing of precipitates and not using press-forming. The compressive strength of the $70 \mathrm{wt} \%$ less HA containing glasses are sufficiently larger than those of cortical bone and cancellous bone (89-164 MPa and 1.9-7.0 $\mathrm{MPa}$, respectively ${ }^{18)}$ ).

Figure 4 shows the relationship between the Vick- ers hardness and the HA content in the glass. The Vickers hardness of the glass linearly decreases according to the increase of HA content. The Vickers hardness of the glass (680 VHN) is nearly the same as that of Pylex glass (706 VHN) and much larger than that of enamel of human teeth (360-370 VHN). Therefore, the value of about $70 \mathrm{wt} \%$ HA containing glass corresponds to that of natural teeth.

Figure 5 shows the DSC curves of $30 \mathrm{wt} \%$ (b) and

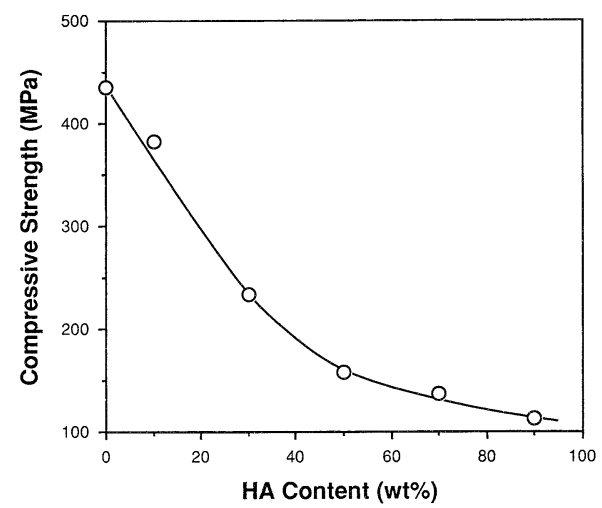

Fig. 3. Compressive strength of HA containing glasses.

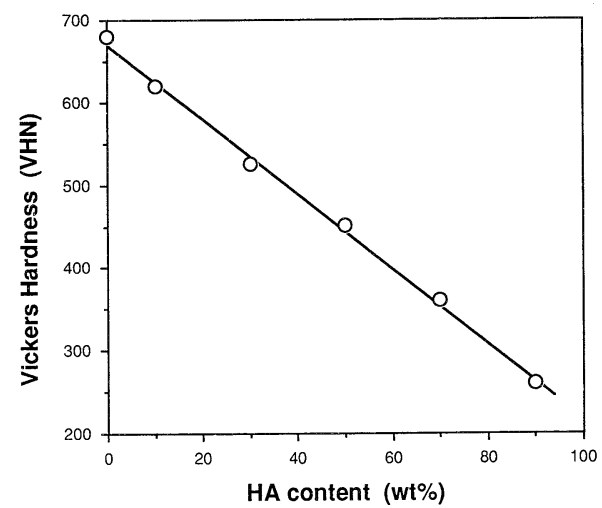

Fig. 4. Vickers hardness of HA containing glasses.

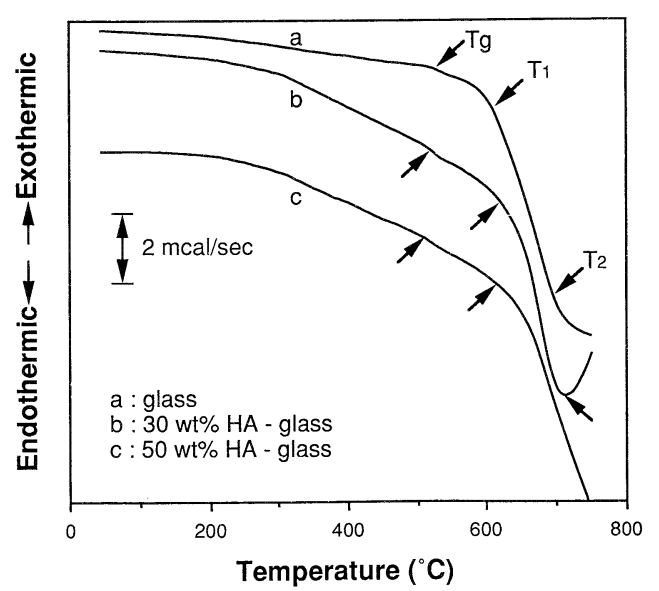

Fig. 5. DSC curves of $30 \mathrm{wt} \%$ and $50 \mathrm{wt} \% \mathrm{HA}$ containing glass and the pure glass. $T_{\mathrm{g}}$ is glass-transition temperature, $T_{1}$ sintering temperature, and $T_{2}$ softening temperature. 
$50 \mathrm{wt} \%$ HA (c) containing glass samples and the glass sample (a) fired at $950^{\circ} \mathrm{C}$. The glass-transition temperature $\left(T_{\mathrm{g}}\right)$, sintering temperature $\left(T_{1}\right)$ and softening temperature $\left(T_{2}\right)$ of the fired glass were determined as $523^{\circ}, 629^{\circ}$ and $671^{\circ} \mathrm{C}$, respectively, where $T_{1}$ was obtained as the temperature changing drastically between the $T_{\mathrm{g}}$ and the $T_{2}$ in endothermic trace. From the comparison of the DSC curves of both $30 \mathrm{wt} \%$ and $50 \mathrm{wt} \% \mathrm{HA}$ containing glass samples with that of the glass sample, it is confirmed that the glass little reacted with $\mathrm{HA}$ at firing temperature $\left(950^{\circ} \mathrm{C}\right)$. Because, if the dispersed HA particles reacted with glass at the firing temperature, resulting in the change in the glass component, the considerable difference in $T_{\mathrm{g}}, T_{1}, T_{2}$ of the HA containing glass for those of the glass should be appeared in DSC curves. The resulting X-ray diffraction also showed that the diffraction intensity from HA crystal phase increased with increase in HA concentration in the glass.

Figure 6 shows change in thermal expansion coefficient of HA containing glasses. The glass has a linear thermal expansion coefficient $\left(7.8 \times 10^{-6} /{ }^{\circ} \mathrm{C}\right)$ several percent smaller than those of the $\mathrm{Ti}$ and $\mathrm{Ti}$ $6 \mathrm{Al}-4 \mathrm{~V}\left(8.7 \times 10^{-6} /{ }^{\circ} \mathrm{C}\right.$ and $9.4 \times 10^{-6} /{ }^{\circ} \mathrm{C}$, respectively) at the temperature range from $30^{\circ} \mathrm{C}$ to $400^{\circ} \mathrm{C}$. The thermal expansion coefficient of glass-HA ceramics markedly increases beyond the HA content about $35 \mathrm{wt} \%$. Namely, although there was little change in the thermal expansion coefficient of HA containing glasses by the addition of $30 \mathrm{wt} \%$ less $\mathrm{HA}$, that of $50 \mathrm{wt} \%$ more HA containing glasses increased with the addition of HA. This seems to be due to the fact that the thermal expansion coefficient of $\mathrm{HA}\left(13.3 \times 10^{-6} /{ }^{\circ} \mathrm{C}\right)$ was much higher than that of the glass. It is well known in enameling that the small difference in thermal expansion coefficient between coating glass and metal substrate is very important for the excellent bonding between them; i.e., thermal expansion coefficient of glass is several percent smaller than that of metal substrate. Thus, it is concluded that the glass and low content of HA con-

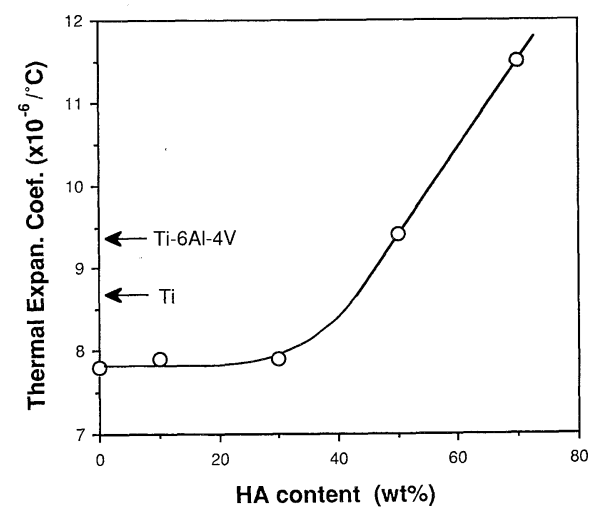

Fig. 6. Thermal expansion coefficient of HA containing glasses. The value of $\mathrm{Ti}-6 \mathrm{Al}-4 \mathrm{~V}$ and pure Ti metals are shown in reference. taining glasses are suitable coating materials for $\mathrm{Ti}$ and $\mathrm{Ti}-6 \mathrm{Al}-4 \mathrm{~V}$ and the gradient concentration of HA containing glass layer to the outermost coating layer is able to relieve the thermal stress due to the difference in thermal expansion coefficient between glass-HA layer and $\mathrm{Ti}$ or Ti-6Al-4V substrate.

3.2 Bonding strength between HA containing glass and $\mathrm{Ti}$

The adhesion, bonding strength, of glass to Ti substrate, which was evaluated by the pull-out test, depends on the surface roughness of the substrate and reached the maximum value of $28 \mathrm{MPa}$ under the condition of $2.3 \mu \mathrm{m}$ in the center line average, $H_{\text {CLA }}$. This maximum strength is very high compared with bonding strength of pure titanium to porcelains ${ }^{19)}$ and in porcelain-gold alloy systems. ${ }^{20)}$

Figure 7 shows the relationship between the pullout strength and the HA content in the glass. The pull-out strength for the HA containing glass composite with the Ti substrate subjected to sandblasting (the average surface roughness $3.4 \mu \mathrm{m}$ in $H_{\text {CLA }}$ )

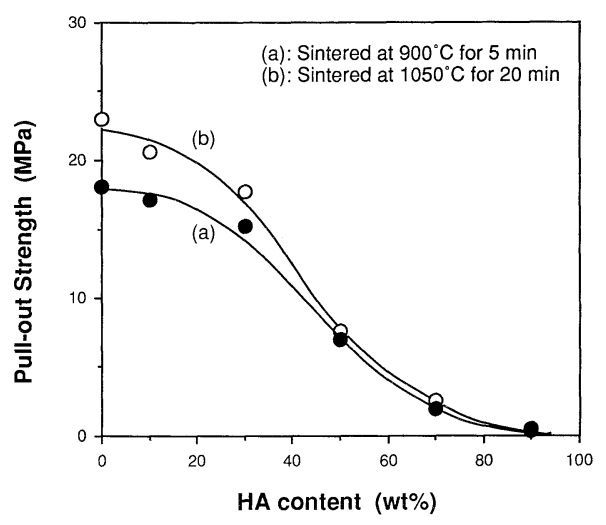

Fig. 7. Pull-out strength of HA containing glass-Ti composite, sintered at $900^{\circ} \mathrm{C}$ for $5 \mathrm{~min}$ (a) and $1050^{\circ} \mathrm{C}$ for $20 \mathrm{~min}$ (b). The sandblasted Ti rod having the surface roughness $3.3 \mu \mathrm{m}$ (center line average: $\left.H_{\mathrm{CLA}}\right)$ was used.

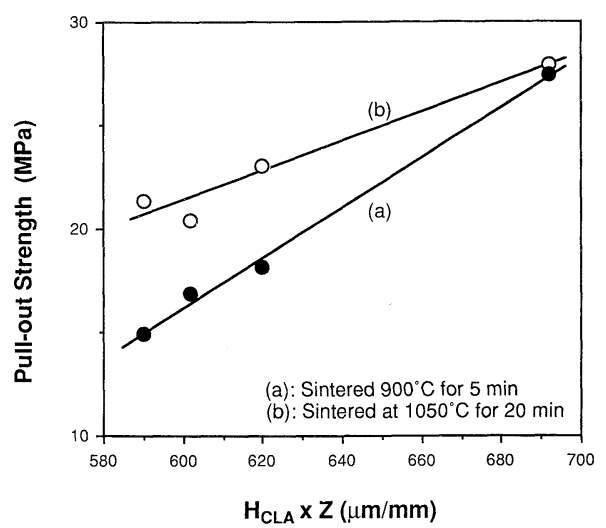

Fig. 8. Relation between pull-out strength and average surface roughness frequency $\left(H_{\mathrm{CLA}} \times Z\right)$ of base metal for glass-Ti composites, sintered at $900^{\circ} \mathrm{C}$ for $5 \mathrm{~min}$ (a) and $1050^{\circ} \mathrm{C}$ for $20 \mathrm{~min}$ (b). $H_{\text {CLA }}$ is center line average and $Z$ number of unevenness per unit length $(1 \mathrm{~mm})$. 
decreases with increasing in the HA content of the glass layer. It seems that the pull-out strength is strongly affected by the compressive strength of HA containing glass layer.

Figure 8 shows the relationship between the pullout strength and the average surface roughness frequency of the surface of substrate. The pull-out strength linearly increases with increasing of the average surface roughness frequency of the surface of the substrate.

Figure 9 shows the distribution of the main components ( $\mathrm{Si}, \mathrm{O}$ and $\mathrm{Ti}$ ) of glass and substrate analyzed by the EPMA, at the interface between Ti and glass fired at three kinds of temperatures and periods. It is found that Si has a small peak of concentration distribution at the interface and Ti diffuses to the glass frit layer as the firing temperature is increased. Furthermore, the depth of the oxide layer at the interface increases with firing temperature. In general, in the adhesion of glass to metal, the stable thin oxide layer is effective for the increases in bonding strength between the glass and metal. However, although the glass frit was transparent, the interface became to be more black for higher firing temperature. X-ray diffraction studies revealed that there was the formation of $\mathrm{Ti}_{5} \mathrm{Si}_{3}$ and $\mathrm{TiO}$ at a portion adjacent to the oxide layer on the intermediate glass layer. Thus, it seems that $\mathrm{SiO}_{2}$ in the glass frit reacts with Ti substrate as follows:

$$
11 \mathrm{Ti}+3 \mathrm{SiO}_{2} \rightarrow \mathrm{Ti}_{5} \mathrm{Si}_{3}+6 \mathrm{TiO} .
$$

Therefore, we employed the preparation condition for the HA-G-Ti composite that a substrate was sandblasted to make a center line average roughness of $2.3 \mu \mathrm{m}$ and the glass was only coated on the substrate at firing temperature from $900^{\circ} \mathrm{C}$ to $950^{\circ} \mathrm{C}$ for $3 \mathrm{~min}$ to make a strong bonding layer, and then the mixture of glass and HA with gradually different contents was repeatedly coated. The HA content increased from the inner layer toward the outer layer as shown in Fig. 2.

3.3 Formation of bioactive surface on the composite and application for implant

Figure 10 shows the SEM photographs of the surface of $50 \mathrm{wt} \% \mathrm{HA}-\mathrm{G}-\mathrm{Ti}$ composite etched in a mix-

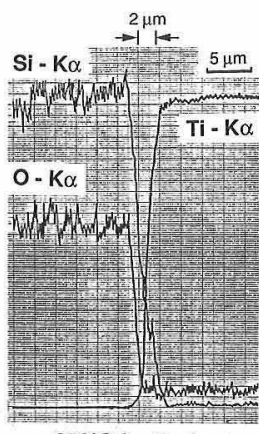

$950^{\circ} \mathrm{C}$ for $5 \mathrm{~min}$

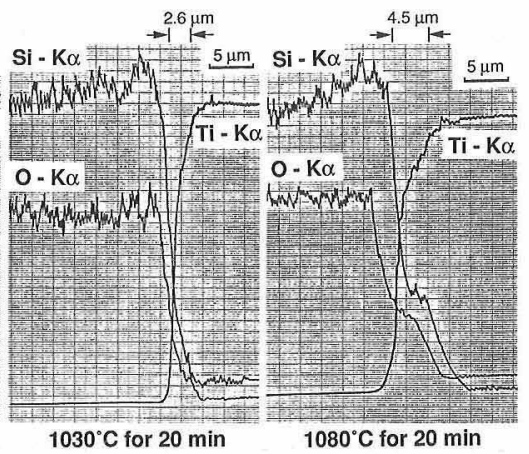

Fig. 9. EPMA line analyses at the interface between $\mathrm{Ti}$ and glass fired at various temperatures in air.
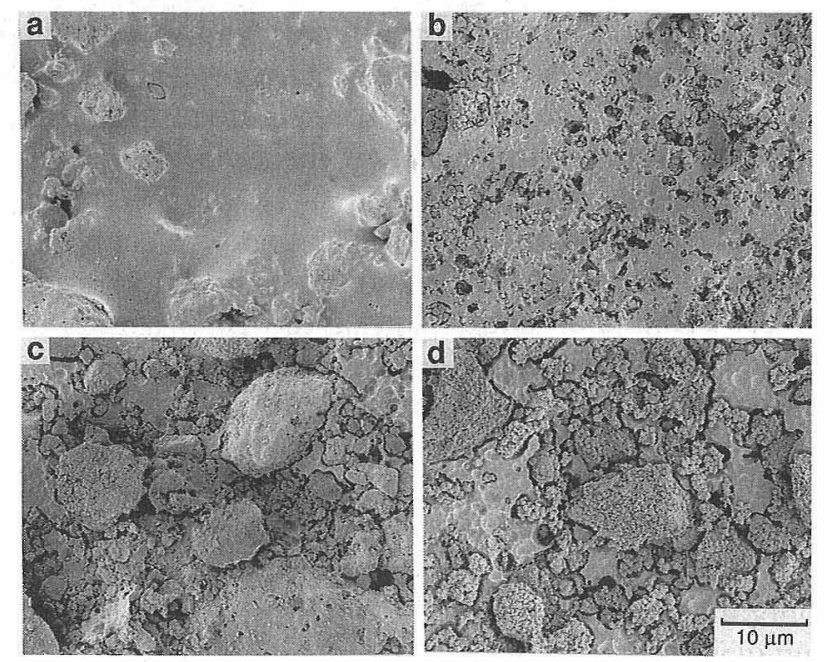

Fig. 10. SEM photographs of the surfaces of $50 \mathrm{wt} \% \mathrm{HA}$ containing glass-coated titanium composites etched in mixed solution of $3 \% \mathrm{HF}$ and $5 \% \mathrm{HNO}_{3}$ for various times. (a) as coated, (b) 1 $\min$, (c) $3 \mathrm{~min}$ and (d) $15 \mathrm{~min}$.

ture of $3 \% \mathrm{HF}$ and $5 \% \mathrm{HNO}_{3}$ for various time. This etching solution was the most suitable for preparing a bioactive surface layer of HA-G-Ti composite, since the glass was removed, a great number of $\mathrm{HA}$ particles were exposed, and little $\mathrm{CaF}_{2}$ was produced by the etching. ${ }^{14)}$ The change in surface character due to the etching process is remarkable for the composite surface. A great number of fine HA particles stuck together on the glass of the glass-HA ceramic layer appear on an etched surface of uneven and roughened state, wherein microcracks in order of microns in width and many voids several microns in size are present. Such a texture is considered suitable for apposition of HA-G-Ti composite to bone.

Figure 11 shows the Roentogenogram of dog's femur bone with three bars of HA-G-Ti composite implants. The radio-opaque zone, probably due to the calcification of bone matrix and the formation of callous bone, is observed extending from around the boneburied portion of implant towards the inner por-

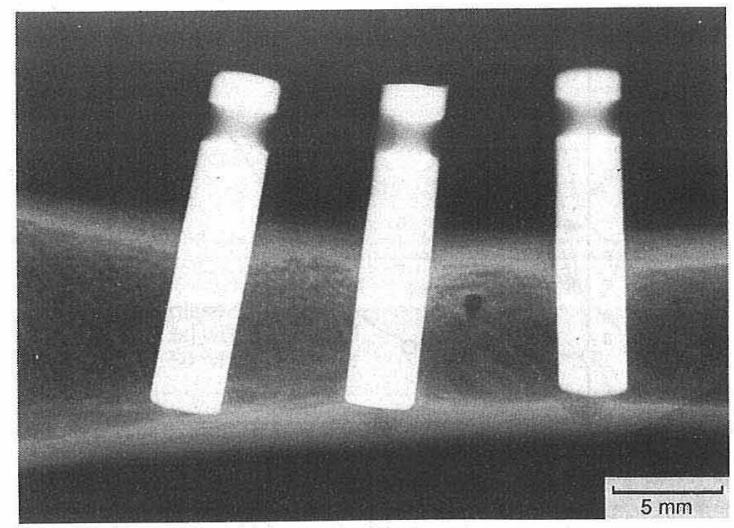

Fig. 11. Roentogenogram (positive) showing the contact of implants and bone after 2 month implantation. 
tion of bone along the implant. No bone resorption is apparent. It has been found that all slits and spaces disappear and the implants are well integrated into the surrounding bone.

Figure 12 shows the SEM photographs of transverse section of implants at the parts in contact with cortical bone and cancellous one. A concentric ring of trabecular bone is observed around the implant rod with bone in the apposition to the HA containing glass layer. Although the damage of the HA containing glass layer by diamond cutter blade can be seen, the implant is tightly in contact with the surrounding bone tissue. Moreover, there are no indications that the presence of the implant has disturbed the normal process of bone breakdown and renewal. In the histological examination of the undecalcified thin sections, no inflammation and resorption were recognized in bone tissue being contacted with the implant.

It was concluded that HA-G-Ti functionally
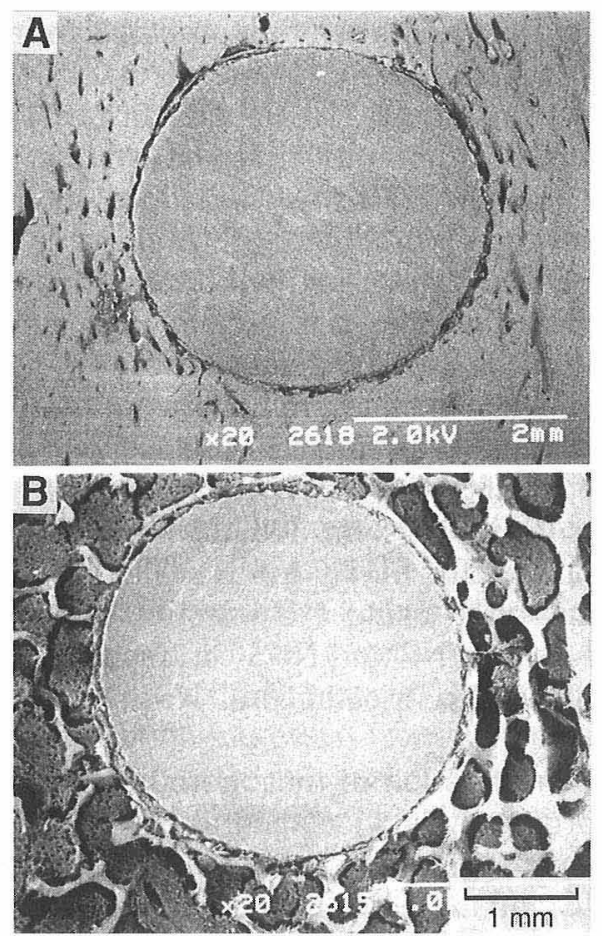

Fig. 12. SEM photographs of transverse section of HA-G-Ti composite implant, embedded in dog femur for two months, and adjacent bone tissue. $\mathrm{A}$ and $\mathrm{B}$ show the parts contact with cortical bone and cancellous one, respectively. gradient composite is an excellent biomaterials applicable to the cementless artificial joints and dental implants.

Acknowledgement The authors are grateful to Mr. K. Imamura for his technical assistance. This research was partially supported by a Grant-in-Aid for Developmental Scientific Research (No. 02559009) and a Grant-in-Aid for General Scientific Research (No. 03670930) from the Ministry of Education, Science and Culture of Japan.

\section{References}

1) E. A. Monroe, W. Votawa, D. B. Bass and J. McMullen, $J$. Dent. Res., 50, 860-61 (1971).

2) S. N. Bhaskar, J. M. Brady, L. Getter, M. F. Grower and T. Driskel, Oral Surg., 32, 336-46 (1971).

3) K. de Groot, Biomaterials, 1, 47-50 (1980).

4) H. W. Denissen, K. de Groot, P. Ch. Makkes, A. van den Hoff and P. J. Klopper, J. Biomed. Mater. Res., 14, 713-21 (1980).

5) K. de Groot, "Biocompatibility of Clinical Implant Materia1s", Vol. I, Ed. by D. F. Williams, CRC Press (1981) pp. 199-225.

6) R. G. T. Geesink, K de Groot and C. P. A. T. Klein, Clin. Orthop. Rel. Res., 225, 147-79 (1987).

7) W. R. Lacefield, Anals N. Y. Academy Sci., 523, 72-80 (1988).

8) G. W. Hastings, D. Dailly and S. Morrey, "Bioceramics", Vol. I, Ed. by H. Ohnishi, H. Aoki and K. Sawai, Ishiyaku EuroAmerica (1989) pp. 355-58.

9) S. Maruno, Y. F. Wang, H. Iwata, H. Itoh and S. Ban, Abst. Ann. Meet. Ceram. Soc. Japan, Nagoya (1987) pp. 959-60.

10) S. Maruno, K. Hayashi, Y. Sumi, Y.F. Wang and H. Iwata, "Handbook of Bioactive Ceramics", Vol. II, Ed. by T. Yamamuro, L. L. Hench and J. Wilson, CRC Press (1990) pp. 187-93.

11) H. Iwata, S. Maruno, H. Itoh, S. Ban, K. Hayashi and T. Ishikawa, "Bioceramics", Vol. 1, Ed. by H. Ohnishi, H. Aoki and K. Sawai, Ishiyaku EuroAmerica (1989) pp. 411-16.

12) S. Maruno, S. Ban, H. Itoh, H. Iwata,. J. Hasegawa and T. Ishikawa, "Bioceramics" Vol. 2, Ed. by G. Heimke, German Ceramic Society (1990) pp. 321-29.

13) S. Maruno, H. Itoh, S. Ban, H. Iwata and T. Ishikawa, Biomaterials, 12, 225-30 (1991).

14) S. Ban, S. Maruno and J. Hasegawa, Jpn. J. Appl. Phys., 29, L1523-26 (1990).

15) S. Ban, J. Hasegawa and S. Maruno, Biomaterials, 12, 20509 (1991).

16) S. Ban, S. Maruno and J. Hasegawa, Jpn. J. Appl. Phys., 30, L1333-36 (1991).

17) G. Daculsi, R. Z. LeGeros, E. Nery, K. Lynch and B. Kerebel, J. Biomed. Mat. Res., 23, 883-94 (1989).

18) J. D. Currey, Clin. Orthop. Rel. Res., 73, 210-31 (1970).

19) T. Togaya, M. Suzuki, S. Tsutsumi and K. Ida, Dent. Mat. J., 2, 210-19 (1983).

20) R. C. Vickery and L. A. Badinelli, J. Dent. Res., 47, 683-89 (1968). 